\title{
METHOD OF PRODUCTION OF WHOLE-MUSCLE BAKED PORK PRODUCTS
}

\author{
${ }^{1,2}$ Сложенкина М.И., доктор биологических наук, профессор \\ ${ }^{1,2}$ Горлов И.Ф., доктор сельскохозяйственных наук, профессор, академик РАН \\ ${ }_{1,2}$ Княжеченко O.A., младший научный сотрудник \\ ${ }^{2}$ Павлова Е.А., студентка
}

${ }^{1,2}$ Slozhenkina M.I., doctor of biological sciences, professor

${ }^{1,2}$ Gorlov I.F., doctor of agricultural sciences, professor, academician of RAS

${ }^{1,2}$ Knyazhechenko O.A., junior scientific researcher

${ }^{2}$ Pavlova E.A., student

${ }^{1}$ Поволжский научно-исследовательский институт производства и переработки мясомолочной продукции, Волгоград

${ }^{2}$ Волгоградский государственный технический университет

${ }^{1}$ Volga region research institute of manufacture and processing of meat-and-milk production, Volgograd

${ }^{2}$ Volgograd state technical university

В статье приведены сведения о способе производства цельномышечных запеченных изделий из свинины, а именно карбонада, с повышенным содержанием селена, фосфора, а также инулина и возможности повышения качества и биологической ценности данных изделий путем улучшения их органолептических и физико-химических свойств при одновременном увеличении эффективности процесса посола. Рассмотрен способ производства продукта.

Data on a way of production the baked products from pork, namely carbonade, with the increased content of selenium, phosphorus and also an inulin and improvement of quality and the biological value of these products by improvement of their organoleptic and physical and chemical properties are provided in article at simultaneous augmentation of efficiency of process of a salting. The way of production of a product is surveyed.

Ключевые слова: инулин, селен, фосфор, витамины, карбонад, пищевые волокна, минеральная недостаточность.

Keywords: inulin, selenium, phosphorus, vitamins, carbonade, alimentary fibers, mineral failure. 
В настоящее время замечено, что в подавляющем большинстве регионов России рационы питания людей бедны кобальтом; высокий уровень смертности и низкая продолжительность жизни отмечаются в Волгоградской области, где не хватает селена и фосфора [3]. Без селена высок риск развития рака различной этиологии, болезней сердечно-сосудистой системы, нарушения работы щитовидной железы; без фосфора плохо синтезируется белок, и человек становится менее энергичным и сильным. Исходя из необходимости обогащения мясных продуктов эссенциальными микроэлементами, при разработке технологии карбонада было решено включить в рецептуру ингредиенты, богатые кобальтом, фосфором, селеном, витаминами группы В, незаменимыми аминокислотами, такими как: аргинин, валин, лейцин, треонин и другие, а также Омега-3 и Омега-6 жирными кислотами и инулином $[1,2,5]$.

Употребление такого продукта способствует улучшению углеводного обмена, нормализации уровня сахара, активизации процесса сжигания жиров, выводу радионуклидов и тяжелых металлов из организма, улучшению перистальтики кишечника, а также снижению риска развития болезней сердечнососудистой системы и снабжению организма энергией, тем самым помогая организму переносить нагрузки и повышая работоспособность $[4,5,6]$.

Разрабатываемый продукт питания - это карбонад запеченный, в способе производства которого в качестве функциональных ингредиентов используют сочетание сока топинамбура, зубчиков чеснока и розмарина. В качестве мясного сырья используют нежные спинную и поясничную мышцы (филей) с толщиной шпика не более 0,5 см от свиных полутуш. Готовый продукт получается мягким, сочным и упругим.

На рынке потребителей карбонад запеченный пользуется меньшим спросом в отличие от копчено-вареных или копчёно-запеченных продуктов из свинины в виду того, что имеет достаточно высокую себестоимость. Однако карбонад изготавливается из мяса наиболее ценных частей туши с наименьшим содержанием жировой ткани, что является большим его достоинством.

Функциональным ингредиентом растительного происхождения, входящим в состав посолочной смеси, является сок клубней топинамбура. В нем содержится высокое количество такого витамина, как тиамин (в 100 г - 13\% от суточной нормы), он достаточно богат минеральными элементами, фитостеролами $(16,4 \%)$, полисахаридом инулином (в 100 г - 14 г), моносахаридом маннозой (в 100 г - 14,3\% от суточной нормы), клетчаткой $(18 \%)$ [4,6,7]. Полисахарид фруктанового типа - инулин, содержащийся в значительных количествах в клубнях топинамбура, снижает риск развития сахарного диабета, поскольку является регулятором углеводного обмена: в кислой среде желудочного сока инулин под воздействием фермента инулазы частично гидролизуется с образованием молекул фруктозы, которая усваивается организмом без инсулина, предупреждая тем самым энергетический голод тканей больных сахарным диабетом, одновременно снижая чувство голода [6].

Кроме того, инулин участвует в тех же обменных процессах, что и глюкоза, и замещает ее в ситуациях, когда глюкоза клетками не усваивается; улучшает липидный обмен, положительно влияет на кишечную флору (имеет бифи- 
догенную активность, является пребиотиком, то есть питательной средой для размножения полезных бактерий), ускоряет очищение организма от шлаков и вредных веществ. Установлено, что при воздействии высоких температур при приготовлении продуктов питания количество инулина сохраняется на 70\% [6]. В топинамбуре, а также в его соке содержится до $8 \%$ кремния, что делает его особенно полезным для лиц пожилого возраста. Характерная биоадаптогенная активность различных инулинсодержащих продуктов топинамбура послужила основанием для их применения с целью стимулирования физических функций организма (для спортсменов, военнослужащих, рабочих, осуществляющих тяжелую физическую работу). Средний химический состав клубней топинамбура представлен в таблице 1 [6].

Таблица 1 - Средний химический состав топинамбура

\begin{tabular}{|l|c|}
\hline \multicolumn{1}{|c|}{ Состав } & Содержание в клубнях, \% \\
\hline Сухие вещества & 22,5 \\
\hline Вода & 77,5 \\
\hline Сахара & 16,9 \\
\hline Целлюлоза & 1,9 \\
\hline Жиры & 0 \\
\hline Белок & 2,3 \\
\hline Зола & 1,1 \\
\hline
\end{tabular}

Среди минеральных элементов сока клубней топинамбура преобладают: бор (143\%), кремний (27\%), ванадий (24\%), хром (24\%), железо (19\%), калий (17\%), никель (15\%), молибден (14\%), медь (14\%), фосфор (10\%), кобальт $(10 \%)$.

Выбор других составляющих посолочной смеси - чеснока и розмарина подтверждают следующие аргументы: высокая пищевая и биологическая ценность, большое количество макро-, микроэлементов и витаминов, что оказывает положительное влияние на организм человека, нормализует работу сердечнососудистой и пищеварительной систем, а также способствует повышению активности.

Карбонад, получаемый заявленным способом, готовится по технологии изготовления изделий запеченных из мяса, принятой для производства цельномышечных запеченных изделий из свинины. Свинину жилованную в количестве 100 кг натирают розмарином и вручную шпигуют зубчиками чеснока, взятыми в количестве 2,5 и 3,3 кг соответственно, в то же время на соковыжималке проводят выжимку сока из клубней топинамбура в количестве 33,3 кг. Далее натертое специями мясное сырье замачивают в предварительно подготовленном рассоле, в состав которого входят следующие ингредиенты: сок топинамбура, 1,7 кг соли поваренной пищевой, 2,9 кг перца черного молотого душистого, 5,0 кг масла растительного и 16,7 кг воды питьевой. Мясное сырье массируют в вакуумном массажере при 14 об/мин. в течение 30 мин., оставляют на выдержку и созревание в течение 12-14 ч. После чего мясное сырье укладывают в термоустойчивый рукав для запекания и подвергают термообработке в режиме запекания при температуре $180-200^{\circ} \mathrm{C}$ в течение $2-2,5$ ч (до достижения $72^{\circ} \mathrm{C}$ в центре продукта) с последующим охлаждением готовой продукции до дости- 
жения температуры в толще не выше $0-8^{\circ} \mathrm{C}$. Полученный готовый продукт упаковывают в вакуумную упаковку на вакуумной упаковочной линии и укладывают в тару. Карбонад готовится без химических добавок, поэтому он натурального серовато-коричневого цвета с приятным запахом специй и слегка сладковатым вкусом благодаря использованию сока топинамбура.

Полученные таким способом цельномышечные запеченные изделия из свинины, а именно карбонад, характеризуются высокой пищевой ценностью, улучшенным химическим составом за счет обогащения пищевыми волокнами (инулином), высоким содержанием минеральных элементов и витаминов группы В, низкой калорийностью, а также выраженными вкусовыми характеристиками. Также был проведен сравнительный анализ пищевой ценности образца экспериментального (с соком топинамбура, чесноком и розмарином) и образца контрольного с использованием рассола классической рецептуры. Пищевая ценность исследуемых образцов приведена в таблице 2.

Таблица 2 - Пищевая ценность образцов

\begin{tabular}{|l|c|c|}
\hline \multirow{2}{*}{\multicolumn{1}{|c|}{ Показатель }} & \multicolumn{2}{|c|}{ Содержание в 100 г изделия } \\
\cline { 2 - 3 } & эксперимент & контроль \\
\hline Массовая доля жира, г & 20,0 & 20,0 \\
\hline Массовая доля белка, г & 20,0 & 14,0 \\
\hline Массовая доля углеводов, г & 15,0 & 0,0 \\
\hline Энергетическая ценность, ккал & 380 & 236 \\
\hline
\end{tabular}

Сравнительный анализ пищевой и энергетической ценности выявил превосходство образца карбонада, выработанного по новой рецептуре, над контрольным. Так, содержание белка в нем выше на 6,0 г, углеводов - на 15,0 г, а энергетическая ценность выше на 144 ккал. Это объясняется тем, что в производстве заявленного продукта используется нежирная свинина и сок топинамбура, химический состав которых содержит соответственно: белки - 17-20\%, жиры - 27\%, углеводы - 0\%; белки - 2,3\%, жиры - 0,1\%, углеводы - 18,8\%, пищевые волокна (инулин) - до 70\%.

\section{Библиографический список}

1. Горлов, И.Ф. Инновационные технологии управления живыми системами в производстве высококачественной экологически безопасной продукции животноводства / И.Ф. Горлов // Известия Нижневолжского агроуниверситетского комплекса: наука и высшее профессиональное образование. - 2014. - № 3 (35). - С. 104-115.

2. Горлов, И.Ф. Системные технологии продсырья и продуктов как основа повышения конкурентоспособности АПК / И.Ф. Горлов // Вестник мясного скотоводства. - Оренбург, 2005. - № 58.- С. 15-22.

3. Дефицит микроэлементов в разных регионах России [Электронный реcypc] https://www.volgograd.kp.ru/daily/26621.5/3639072/ (Дата обращения: 13.03.2018).

4. Сложенкина, М.И. Использование топинамбура для улучшения потребительских и функционально-технологических свойств ветчинных изделий / 
М.И. Сложенкина, О.А. Княжеченко, И.Ф. Горлов, С.В. Шинкарева // Известия Нижневолжского агроуниверситетского комплекса: наука и высшее профессиональное образование. - 2017. - № 3 (47). - С. 141-145.

5. Горлов, И.Ф. Улучшение потребительских свойств мясных продуктов за счет биологически активных веществ / И.Ф. Горлов, М.И. Сложенкина, И.С. Бушуева // Хранение и переработка сельхозсырья. - 2013. - № 5. - С. 32-33.

6. Топинамбур: биология, агротехника выращивания, место в экосистеме, технологии переработки (вчера, сегодня, завтра): монография / Р.И. Шаззо, В.Г. Кайшев, Р.А. Гиш, Р.И. Екутеч, Е.П. Корнена; ГНУ Краснодарский НИИ хранения и переработки с.-х. продукции; под ред. Р.И. Шаззо. - Краснодар: Издательский Дом - Юг, 2013. - 184 с.

7. Тутельян, В.А. Нормы физиологических потребностей в энергии и пищевых веществах для различных групп населения Российской Федерации: методические рекомендации / В.А. Тутельян, А.К. Батурин. - Москва, 2008. - 42 c. 